\title{
Jackfruit Membrane as New Biomaterials for Bio-Catalytic Application in Detection of Urea
}

Kumar $\mathrm{J}^{*}$ and Melo JS

Nuclear Agriculture and Biotechnology Division, Bhabha Atomic Research Centre, Trombay, Mumbai, India

\begin{abstract}
Immobilization of enzymes on a variety of different matrices has always attracted researchers to improve the functionality, stability and reusability and its application in bioprocess and biosensors. Present study illustrates a new biological material, jackfruit membrane, as a natural support for immobilization of the urease enzyme for optical detection of urea. A simple protocol was optimized for immobilization of urease enzyme on the membrane. Km of immobilized urease $(13.8 \mathrm{mM})$ was less than that of free urease $(39.24 \mathrm{mM})$. SEM and FTIR studies of the urease immobilized membranes were carried out to characterize the changes after immobilization. Immobilized urease has shown good reusability and stability. Further, immobilized urease was applied for detection study and a detection range between $0.5-10 \mathrm{mM}$ urea was estimated from the linear range of the calibration plot.
\end{abstract}

Keywords: Jackfruit membrane; Natural polymer; SEM; Urease; Optical detection; Urea

\section{Introduction}

Immobilization of enzymes on a variety of different matrices has always attracted researchers to improve their functionality and reusability. Immobilized enzymes are used as a biocomponent for development of bioprocess and biosensors. In this direction a large number of techniques and support have been used in our laboratories for the immobilization of biocatalyst [1-20]. The choice of support and techniques should be such that it maintains the enzyme activity and has reusability as well as storage stability $[1,2]$. A variety of synthetic as well as natural polymers has been exploited for immobilization of enzymes and had proven their applications. Natural polymers like ocimum seeds, eggshell membrane, bamboo inner shell membrane and inner epidermal onion membrane have been proved to be useful support for enzyme immobilization and its application $[4,7,9,10,15,21,22]$. Since natural polymers in living organisms are composed of biomolecules like carbohydrates, lipid and protein and other secondary metabolites, it had been proven that the microenvironment of the immobilized is mostly favourable for optimum enzyme activity $[4,7,9,10,15]$.

Jackfruit (Artocarpus heterophyllus) belongs to family Moraceae is an integral part of common Indian diet and is freely available in India and adjoining continents, its medicinal properties are also mentioned in Ayurveda. A high content of malic acid is found in unripe fruit (Day 1) and in contrast, ripened fruit (Days 5 and 6) contains a high amount of citric acid as reported earlier [23]. Ripe fruit consists of large, pleasant flavored yellow sweet bulbs (fully developed perianths), massed among narrow ribbons of thin, though undeveloped perianths and a central pithy core that constitute 25-30 per cent of the total fruit. Each bulb of fruits encloses a smooth, oval, light brown seed (endocarp) covered by a thin white membrane (exocarp). It consists of the epidermal and sub-epidermal layers of fruits seed, with various classifications based on texture and appearance such as glabrous (no pubescence), glaucous (waxy bloom), finely pubescent, and densely pubescent [24,25]. In this present study, this thin white membrane was used as natural support for the immobilization of urease enzyme and used for the detection of urea. Urease (E.C. 3.5.1.5) promotes the reaction involving the decomposition of urea to give ammonia and carbon dioxide.

$$
\mathrm{NH}_{2} \mathrm{CONH}_{2}+\mathbf{3} \mathrm{H}_{2} \mathrm{O} \stackrel{\text { urease }}{\longrightarrow} \mathbf{2} \mathrm{NH}^{+}+\mathrm{HCO}_{3}{ }^{-}+\mathrm{OH}^{-}
$$

Urease was used for immobilization because this is one of the common and stable enzymes mostly used for biosensors detection of urea. Urea is a by-product, which is often monitored in blood to obtain information on kidney disease. It is generally accepted to be the best marker for evaluating the level of uremic toxins [26]. Guilbault and Montalvo were the first to fabricate a potentiometric urease enzyme electrode for the estimation of urea through its enzyme-catalyzed hydrolysis [27,28]. In one review, Dhawan et al. reported the recent developments of urea biosensor [19]. Many urea biosensors based on the detection of ammonium ion produced by the above enzymatic reaction have been reported [10,15,29-36].

To our knowledge, this is the first report on employing exocarp membrane of jackfruit seed pouch as the solid support for enzyme immobilization and its application. Our studies indicated how this natural polymer can serve as a biocompatible and inexpensive stable support for immobilization of enzyme for further application in detection. Our proposed enzyme immobilized matrix and method are simple and shown a better enzyme activity after immobilization of urease. It was also applied for detection study and proved to be a biocompatible support with a better sensitivity and wide detection ranges.

\section{Materials and Methods}

\section{Materials}

Jack bean urease (E.C. 3.5.1.5) (910 $\mu \mathrm{M}$ units per tablets) was obtained from Sigma Chem. Co. USA. Phenol-analytical grade, Sodium hypochlorite from Fischer Scientific; Sodium hydroxide, Sodium dihydrogen orthophosphate, di-Sodium hydrogen orthophosphate were obtained from Thomas Baker; Urea, Sodium nitro-prusside and

*Corresponding author: Jitendra Kumar, Nuclear Agriculture and Biotechnology Division, Bhabha Atomic Research Centre, Trombay, Mumbai-400085, India, Tel: +912225593832; E-mail: jkumar@barc.gov.in

Received October 25, 2016; Accepted November 02, 2016; Published November 12, 2016

Citation: Kumar J, Melo JS (2016) Jackfruit Membrane as New Biomaterials for Bio-Catalytic Application in Detection of Urea. J Biosens Bioelectron 7: 226. doi: 10.4172/2155-6210.1000226

Copyright: @ 2016 Kumar J, et al. This is an open-access article distributed under the terms of the Creative Commons Attribution License, which permits unrestricted use, distribution, and reproduction in any medium, provided the original author and source are credited. 
Ammonium chloride from Merck. Jackfruit was purchased from local market.

\section{Optimization of immobilization of urease on seed pouch membrane of jackfruit}

A very simple protocol was optimized for immobilization of urease on membrane. Exocarp part of seed pouch membrane of jackfruit was carefully peeled from the fruit seed and cleaned with distilled water. The membranes were first cut into circular shape of equal diameters $(1 \mathrm{~cm})$ and then used for immobilization after washing with buffer. A $100 \mu \mathrm{L}$ of jack bean urease (100 units activity) was loaded onto the membrane and spread properly with a glass rod and allowed to air dry for $1 \mathrm{~h}$. After drying, the membrane was placed in $1 \mathrm{~mL}$ of $50 \mathrm{mM}$ phosphate buffer $\mathrm{pH} 7.0$ to allow the unbound enzyme to get washed off. Membranes were then used for further studies.

\section{Determination of enzyme activity}

The activity of the enzyme urease immobilized on jackfruit membrane was estimated by measuring the amount of the breakdown product ammonia by the "Phenol-Hypochlorite" method [37]. Reaction time allowed for urease enzyme activity was $2 \mathrm{~min}$. The membrane was removed from reaction vessels and then alkaline hypochlorite, phenol and sodium nitro-prusside were added. The ammonia produced in the reaction reacts with alkaline hypochlorite and phenol in presence of catalyst sodium nitro-prusside, to form an indophenol, which is blue in colour. For colour development and quantifying the ammonia concentration, tubes were incubated at room temperature for $25 \mathrm{~min}$. Concentration of ammonia is directly proportional to the absorbance of indophenols at $625 \mathrm{~nm}$.

\section{Catalytic characterization and enzyme kinetics of immobi- lized urease}

Optimum $\mathrm{pH}$ and temperature were studied to check the effect of immobilization on catalytic activity. For optimum $\mathrm{pH}$ determination, acetate and phosphate buffers were used in the $\mathrm{pH}$ range $4.0-8.0$. Temperature was varied in the range $20-50^{\circ} \mathrm{C}$ for determining optimum temperature. Varying concentrations of urea were assayed to determine the maximum velocity of reaction ( $\mathrm{Vmax}$ ) and MichaelisMenten constant $(\mathrm{Km})$. The apparent $\mathrm{Km}$ value was calculated from Lineweaver-Burk plot [38].

\section{SEM study of enzyme immobilized membrane}

An environmental scanning electron microscope (ESEM) (Quanta 200 ESEM, FEI, USA) was employed to observe the surface structure of the seed pouch membrane of jackfruit. For ESEM study, pieces of the membranes were mounted on stubs and the SEM micrographs of the jackfruit membrane (immobilized and unimmobilized) were studied at magnifications 1000X and 10000X.

\section{FT-IR study of urease immobilized membrane}

Membranes were analysed by FTIR spectroscopy and scanned in the range of $4000-400 \mathrm{~cm}^{-1}$ using Jasco, Model FTIR-660 plus.

\section{Optical detection of urea using urease immobilized mem-} brane

Different concentrations of urea $(0.5,2.5,5,10,25,50$ and $100 \mathrm{mM})$ were used for calibration by optical detection using urease immobilized jackfruit membrane and spectrophotometric study was carried out as per "Phenol-Hypochlorite" method mentioned in section 2.3. Linear fit study was also carried out for the calibration of optical detection of urea.

\section{Results and Discussion}

As immobilizing matrices, biological natural polymers have emerged as ideal platform for enzyme immobilization as they provide biocompatible microenvironment around the enzyme. In present work, Jackfruit membrane as one such support matrix was investigated for urease immobilization and its application in detection of urea.

\section{Urease immobilization on jackfruit membrane}

Advantages of the present method over other existing methods are that both immobilizing support as well as the immobilizing technique is simple, natural, and easily available and there is no need of any other chemical like glutaraldehyde, for the binding of enzyme on the matrices. In this study, naturally occurring cross linkers of jackfruit membrane was employed for immobilizing of urease enzyme. In one previous report, it was described, that two dominant acids, malic acid and citric acid were naturally occurring in the jackfruit [23]. Both malic acid and citric acid have already been proven as very good crosslinkers for immobilization of enzyme $[1,39]$. Therefore, these naturally occurring cross-linkers, malic acid and citric acid present in the seed pouch membrane of jackfruit, might play a role in cross-linking the urease enzyme with the other biomolecules present in the membrane and thereby provided a better biocompatible microenvironment for immobilization and optimum functioning of enzyme activity.

Enzyme kinetic studies of urease immobilized on jackfruit membrane

Study was carried out for investigating the kinetics of enzymes after immobilization. Effect of varying urea concentration on the enzyme kinetics was also studied using urease immobilized on jackfruit membrane and compared with the free enzyme. Apparent Km values of free and immobilized enzyme were calculated from Lineweaver-Burk plot. $\mathrm{Km}$ of the immobilized urease was $13.8 \mathrm{mM}$ which was lesser than the $\mathrm{Km}$ of free enzyme $39.24 \mathrm{mM}$. Decrease in $\mathrm{Km}$ indicate that the affinity of enzyme for substrate has increased to some extent after immobilization of urease on jackfruit membrane, which may be due to biocompatible microenvironment provided by this natural membrane.

\section{Characterization of urease immobilized jackfruit membrane by SEM}

Structural morphology of immobilized membrane was also studied using SEM. Result showed that membrane consisted of elongated tubular cells as shown in Figure 1a at $1000 \mathrm{X}$ magnification. The main cell framework consists of microfibrillar cellulose and a variety of biopolymers and biomolecules, therefore it was considered for immobilization of enzyme for optimum enzyme activity. After urease immobilization on surface of jackfruit membrane, many smear like structures were observed on the surface morphology (Figure 1b). SEM micrographs indicated that changes in surface morphology could be related to the immobilization of enzyme on the membrane. Therefore, from this result it can be presumed that enzyme was successfully immobilized on the surface of the membrane.

\section{Characterization urease immobilized jackfruit membrane by FTIR}

FT-IR spectroscopy is an important analytical technique that helps to detect the vibrational characteristics of various functional 
Citation: Kumar J, Melo JS (2016) Jackfruit Membrane as New Biomaterials for Bio-Catalytic Application in Detection of Urea. J Biosens Bioelectron 7: 226. doi: 10.4172/2155-6210.1000226

Page 3 of 5

groups. FT-IR spectra of blank (without immobilization) and urease immobilized jackfruit membrane were recorded (Figure 2) and each peak was assigned its characteristic functionality (Table 1) [38]. It was observed that various new peaks emerged after immobilization of urease on jackfruit membrane. Peaks assigned at 3284, 2875 and 1750 $\mathrm{cm}^{-1}$ were attributed to $\mathrm{N}-\mathrm{H}$ stretching of amines and amide (peptide) and $\mathrm{O}-\mathrm{H}$ stretching of carboxylic acids and alcohol, $\mathrm{C}-\mathrm{H}$ stretch of alkanes and the carbonyl stretch $\mathrm{C}=\mathrm{O}$ of aliphatic esters, ether and aldehydes. Also peaks assigned at 1127 and $1037 \mathrm{~cm}^{-1}$ were attributed to $\mathrm{C}-\mathrm{O}$ stretching of alcohol, ether and esters gr; $\mathrm{C}-\mathrm{N}$ bond stretching of amines and C-C bond (weak) stretching and peak at $1080 \mathrm{~cm}^{-1}$ assigned to $\mathrm{C}-\mathrm{N}$ stretch of aliphatic primary and secondary amines. Results showed the presence enzyme on jackfruit membrane as indicated in term of $\mathrm{C}-\mathrm{N}$ of amines and amide bond in FTIR study.

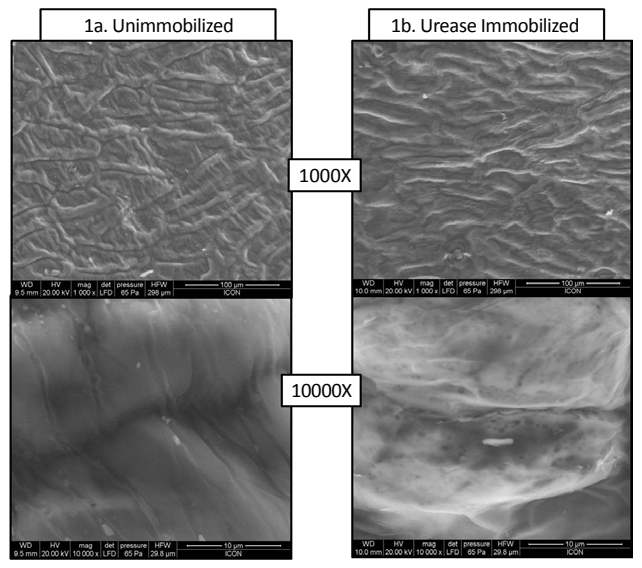

Figure 1: SEM image of urease immobilized jackfruit membrane at 1000 and 10000X. (1a) Unimmobilized, (1b) Urease immobilized jackfruit membrane.

\section{Effect of $\mathrm{pH}$ and temperature on immobilized urease}

The $\mathrm{pH}$ effect was investigated over the range 5.0 - 8.0. Results showed that the optimum $\mathrm{pH}$ for immobilized enzyme was 7.0, which was considered for further study. Optimum temperature was determined by carrying out enzyme substrate reaction at a given temperature. Highest activity was observed in the range of $35-40^{\circ} \mathrm{C}$, after which a gradual fall in activity was observed, however further study was carried out at room temperature to provide ambient and actual condition for detection of urea.

\section{Calibration for optical detection using urease immobilized jackfruit membrane}

Optical detection system was calibrated using different (0.5-100 $\mathrm{mM})$ ) concentrations of urea in association with urease immobilized jackfruit membrane and the absorbance were observed. As shown in Figure 3, a linear fit $\left(\mathrm{Y}=0.20439+0.05615 \mathrm{X} ; \mathrm{R}^{2}=0.9927\right)$ between

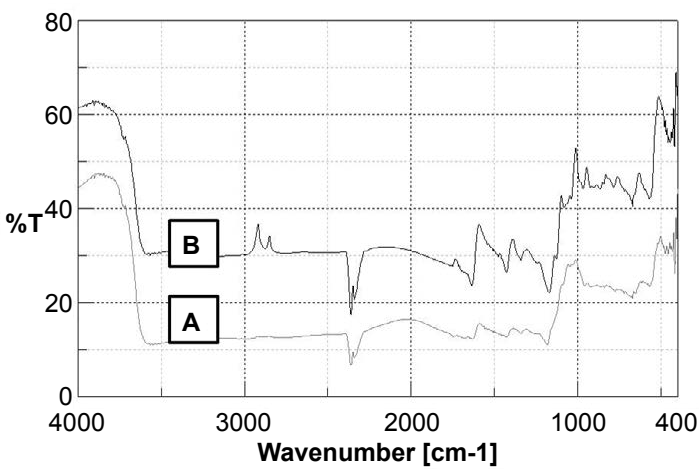

Figure 2: FTIR study of urease immobilized jackfruit membrane.

\begin{tabular}{|c|c|c|}
\hline \multicolumn{2}{|c|}{ Wave number $\left(\mathrm{cm}^{-1}\right)$} & Peak assignments \\
\hline \multirow[t]{5}{*}{$3564 / 3560$} & \multirow[t]{2}{*}{3565} & $\mathrm{O}-\mathrm{H}$ stretching vibration of carboxylic acids and \\
\hline & & $\mathrm{N}-\mathrm{H}$ stretching vibrations of amines \\
\hline & \multirow[t]{2}{*}{$3284 / 3280$} & $\mathrm{~N}-\mathrm{H}$ stretching vibrations of amines \\
\hline & & $\mathrm{O}-\mathrm{H}$ stretching (for hydrogen bonding) vibration of carboxylic acids and alcohols \\
\hline & $2875 / 2875$ & $\mathrm{C}-\mathrm{H}$ (s) stretch of alkanes \\
\hline \multirow[t]{2}{*}{2341 and 2360} & 2341 and 2360 & The spectrum shows carbon dioxide bands $\left(2360\right.$ and $\left.2341 \mathrm{~cm}^{-1}\right)$ from the full oxidation of the hydrocarbon \\
\hline & 1750 & The carbonyl stretch $\mathrm{C}=0$ of aliphatic esters, ether and aldehydes appears \\
\hline \multirow[t]{2}{*}{$1634 / 1631$} & \multirow[t]{2}{*}{$1636 / 1635$} & C-O stretch of amides groups \\
\hline & & $\mathrm{N}-\mathrm{H}$ bending vibration of amines \\
\hline 1434 & $1427 / 1428$ & $\mathrm{v}(\mathrm{C}-\mathrm{O})$ stretching frequency respectively for free carboxylate groups \\
\hline 1338 & 1339 & Symmetric stretching vibrations of the $\mathrm{COOH}$ group \\
\hline \multirow[t]{6}{*}{$1187 / 1184$} & $1170 / 1171$ & $\begin{array}{l}\text { Aklyl-phenyl ether stretching is very strong as comapred with various -C-O-ether stretching modes, which indicates } \\
\text { that alkyl-phenyl ether linkages are predominant }\end{array}$ \\
\hline & \multirow[t]{2}{*}{1127} & C-O strtching of alcohol, ether and esters gr.; C-N bond Stretching of amines \\
\hline & & $\mathrm{C}-\mathrm{C}$ bond (weak) stretching \\
\hline & 1080 & C-N stretch of aliphatic primary and secondary amines \\
\hline & \multirow[t]{2}{*}{1037} & C-O Stretching of alcohol, ether and esthers gr.; C-N bond Stretching of amines \\
\hline & & C-C bond (weak) stretching \\
\hline \multirow[t]{3}{*}{956} & $967 / 967$ & $\mathrm{C}-\mathrm{H}$ benidng of alkene and $\mathrm{C}-\mathrm{N}$ stretch of amines; $\mathrm{CH} 3$ deformation (lipid, protein) \\
\hline & 899 & $\mathrm{C}-\mathrm{C}$ stretch residue; $\mathrm{C}-\mathrm{H}$ bending of alkane, alkene \\
\hline & $864 / 865$ & C-N stretching of amines \\
\hline \multirow[t]{2}{*}{837} & & $\mathrm{~N}-\mathrm{H}$ wag. Of primary and secondary amines \\
\hline & 781 & $\mathrm{C}-\mathrm{H}$ bending of alkane, alkene and benzene; $\mathrm{N}-\mathrm{H}$ wag. of amines \\
\hline $670 / 674$ & $669 / 673$ & $\mathrm{C}-\mathrm{H}$ bending of benzene; $\mathrm{N}-\mathrm{H}$ wag. of amines and amides \\
\hline
\end{tabular}

(A) Only seed pouch membrane of jackfruit, (B) Urease immobilized on the seed pouch membrane of the jackfruit

Table 1: FTIR peaks assignment for urease immobilized seed pouch membrane of jackfruit membrane. 


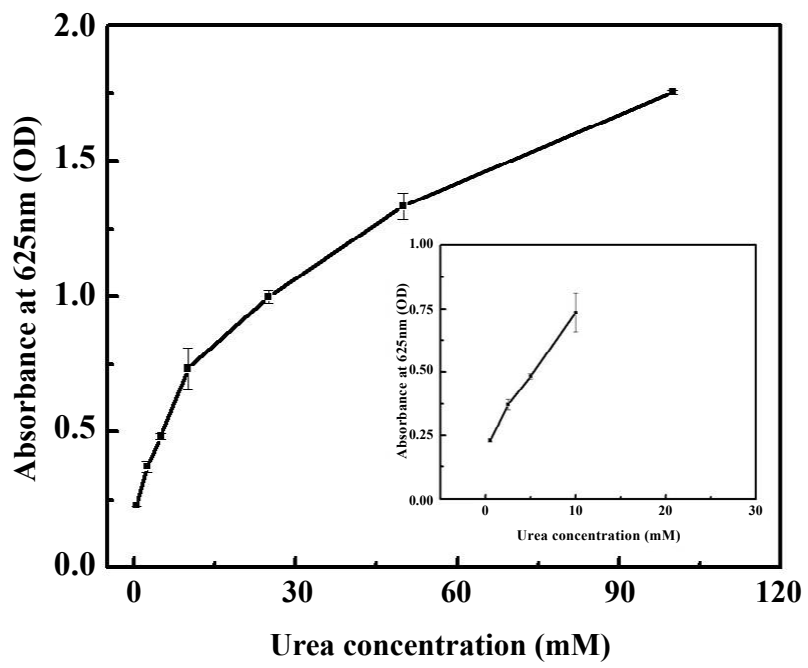

Figure 3: Calibration of optical detection of urea using urease immobilized jackfruit membrane. Inset: Linearity fit of the calibration plot between $0.5-10$ $\mathrm{mM}\left(Y=0.20439+0.05615 X ; R^{2}=0.9927\right)$.

0.5 and $10 \mathrm{mM}$ of urea was estimated using urease immobilized jackfruit membrane. From $10 \mathrm{mM}$ to $100 \mathrm{mM}$ of urea concentration the calibration curve is not linear as shown in Figure 3. Linear range between 0.5 and $10 \mathrm{mM}$ of urea was considered as detection range of the optical detection system. A limit of detection (LOD), $0.2 \mu \mathrm{M}$ was obtained with $\mathrm{S} / \mathrm{N}=3$ in response to the blank sample. Detection range and detection limit of urease immobilized jackfruit membrane was equally comparable to that of the earlier report [10]. Our proposed enzyme immobilization matrix and method is simple and has shown sensitivity as LOD, $0.2 \mu \mathrm{M}$ urea and detection ranges between 0.5 and $10 \mathrm{mM}$. This study reports a new biological natural polymer which can serve as a biocompatible and inexpensive support for immobilization of enzyme for further application in detection.

\section{Reusability, stability and reproducibility of the urease immobilized jackfruit membrane}

Reusability, stability and reproducibility of the urease immobilized jackfruit membrane in response to urea have also been studied to prove the applicability of the new biological natural polymer for detection study. Each membrane showed 38 times reusability with $2.5 \mathrm{mM}$ and $10 \mathrm{mM}$ urea concentration and was stable for 46 days with $10 \mathrm{mM}$ urea concentration with $85 \%$ retention of its initial enzyme activity which inferred the applicability of this natural membrane for urea detection study. The low relative standard deviations $0.25179(\mathrm{n}=6)$ and standard error 0.09517 in response to urea demonstrated the high reproducibility of urease immobilized membrane (Figures 4 and 5).

\section{Conclusion}

We described a new natural polymer, jackfruit membrane, as a solid support for immobilization of the urease enzyme for optical detection of urea. A simple protocol was optimized for immobilization. Enzyme activity of immobilized urease was $(\mathrm{Km}, 13.8 \mathrm{mM})$ which was less than that of free urease $(\mathrm{Km}, 39.24 \mathrm{mM})$. Surface changes of urease immobilized membrane were also studied and characterized by SEM and FTIR. Immobilized urease was applied for urea detection and a detection range between $0.5-10 \mathrm{mM}$ urea was estimated from the linear range of the calibration plot. Immobilized urease has shown a good

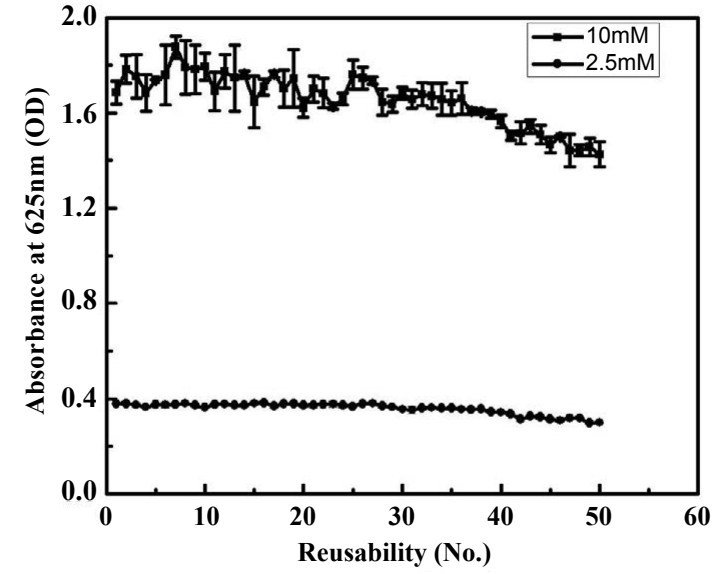

Figure 4: Reusability of the urease immobilized jackfruit membrane.

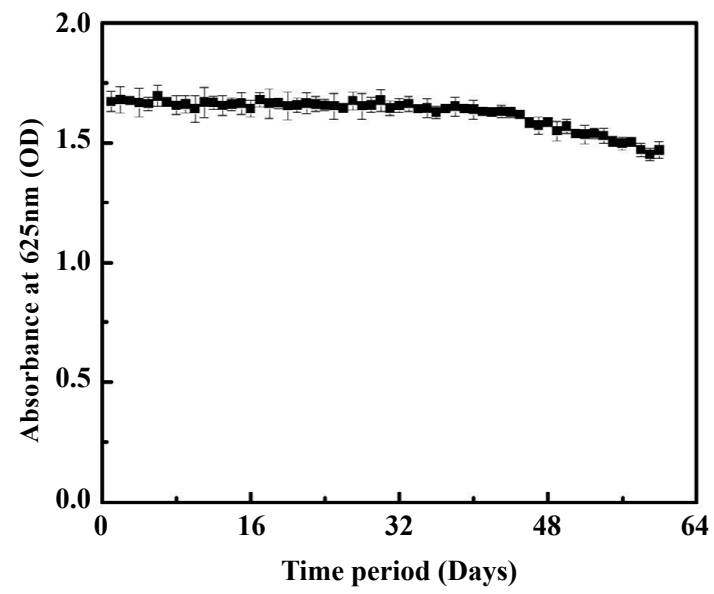

Figure 5: Stability of the urease immobilized jackfruit membrane.

reusability and stability. This is the first report on employing exocarp membrane of jackfruit seed pouch as the solid support for enzyme immobilization and development of biocomponent for detection of urea.

\section{Acknowledgement}

We are grateful to our institute, Bhabha Atomic Research Centre (BARC) for providing financial support.

\section{References}

1. D'Souza SF (2001) Immobilization and stabilization of biomaterials for biosensor applications. Appl Biochem Biotech 96: 225-238.

2. D'Souza SF (2001) Microbial biosensors. Biosens Bioelectron 16: 337-353.

3. Kumar J, D'Souza SF (2008) Preparation of PVA membrane for immobilization of GOD for glucose biosensor. Talanta 75: 183-188.

4. Kumar J, D'Souza SF (2009) Inner epidermis of onion bulb scale: As natural support for immobilization of glucose oxidase and its application in dissolved oxygen based biosensor. Biosens Bioelectron 24: 1792-1795.

5. Kumar J, D'Souza SF (2010) An optical microbial biosensor for detection of methyl parathion using Sphingomonas sp. Immobilized on microplate as a reusable biocomponent. Biosens Bioelectron 26: 1292-1296.

6. Kumar J, D'Souza SF (2011) Microbial biosensor for detection of methy parathion using screen printed carbon electrode and cyclic voltammetry. Biosens Bioelectron 26: 4289-4293. 
Citation: Kumar J, Melo JS (2016) Jackfruit Membrane as New Biomaterials for Bio-Catalytic Application in Detection of Urea. J Biosens Bioelectron 7: 226. doi: 10.4172/2155-6210.1000226

Page 5 of 5

7. Kumar J, D'Souza SF (2011) Immobilization of microbial cells on inner epidermis of onion bulb scale for biosensor application. Biosens Bioelectron 26: 4399-4404.

8. Kumar J, Jha SK, D'Souza SF (2006) Optical microbial biosensor for detection of methyl parathion pesticide using Flavobacterium sp. whole cells adsorbed on glass fiber filters as disposable biocomponent. Biosens Bioelectron 21: 2100 2105.

9. Tembe S, Kubal BS, Karve M, D'Souza SF (2008) Glutaraldehyde activated eggshell membrane for immobilization of tyrosinase from Amorphophallus companulatus: Application in construction of electrochemical biosensor for dopamine. Anal Chim Acta 612: 212-217.

10. D'Souza SF, Kumar J, Jha SK, Kubal BS (2013) Immobilization of the urease on eggshell membrane and its application in biosensor. Mater Sci Eng C 33 : 850-854

11. Kumar J, Melo JS (2015) Microbial biosensors for methyl parathion: from single to multiple samples analysis. Advances in Biosensors Research, Nova Science Publishers, Inc. pp: 89-112.

12. Karimpil J, Melo JS, D'Souza SF (2011) Hen egg white as a feeder protein for lipase immobilization. J Mol Catal B-Enzym 71: 113-118.

13. Karimpil J, Melo JS, D'Souza SF (2012) Immobilization of lipase on cotton cloth using the layer-by-layer self-assembly technique. Int J Biol Macromol 50: 300-302.

14. Manjunatha R, Nagaraju DH, Suresh GS, Melo JS, D'Souza SF, et al. (2011) Electrochemical detection of acetaminophen on the functionalized MWCNTs modified electrode using layer-by-layer technique. Electrochim Acta 56: 66196627

15. Melo JS, D'Souza SF (1992) Immobilization of invertase through its carbohydrate moiety on Ocimum basilicum seed. Appl Biochem Biotechnol 32 : 159-170.

16. Melo JS, D'Souza SF (1999) Simultaneous filtration and immobilization of cells from a flowing suspension using a bioreactor containing polyethylenimine coated cotton threads: Application in the continuous inversion of concentrated sucrose syrups. World J Microbiol Biotechnol 15: 17-21.

17. Melo JS, Sen D, Mazumder S, D'Souza SF (2013) Spray drying as a nove technique for obtaining microbial imprinted microspheres and its application in filtration. Soft Matter 9: 805-810.

18. Mishra A, Melo JS, Sen D, D'Souza SF (2014) Evaporation induced selfassembled microstructures of silica nanoparticles and Streptococcus lactis cells as sorbent for uranium (VI). J Colloid Interface Sci 414: 33-40.

19. Saini AS, Kumar J, Melo JS (2014) Microplate based optical biosensor for I-Dopa using tyrosinase from Amorphophallus campanulatus. Anal Chim Acta 849: 50-56.

20. Mishra A, Kumar J, Melo JS (2017) An optical microplate biosensor for the detection of methyl parathion pesticide using a biohybrid of Sphingomonas $\mathrm{sp}$. cells-silica nanoparticles. Biosens Bioelectron 87: 332-338.

21. Wu B, Zhang G, Shuang S, Choi MMF (2004) Biosensors for determination of glucose with glucose oxidase immobilized on an eggshell membrane. Talanta 64: $546-553$
22. Yang X, Zhou Z, Xiao D, Choi MMF (2006) A fluorescent glucose biosensor based on immobilized glucose oxidase on bamboo inner shell membrane. Biosens Bioelectron 21: 1613-1620.

23. Ong BT, Nazimah SAH, Osman A, Quek SY, Voon YY, et al. (2006) Chemical and flavour changes in jackfruit (Artocarpus heterophyllus Lam.) cultivar J3 during ripening. Postharvest Biol Technol 40: 279-286.

24. Moncur MW (1985) Floral ontogeny of the jackfruit, Artocarpus heterophyllus Lam. (Moraceae). Aust J Bot 33: 585-593.

25. Morton JF (1965) The jackfruit (Artocarpus heterophyllus Lam.); Its culture varieties, and utilization. Proc Fla State Hortic Soc 78: 336-344.

26. Depner TA (1991) Prescribing hemodialysis: A guide to urea modeling. Kluwer Academic Publishers.

27. Guilbault GG, Montalvo J (1969) A urea-specific enzyme electrode. J Am Chem Soc 91: 2164-2165.

28. Guilbault GG, Montalvo J (1969) An improved urea specific enzyme electrode Anal Lett 2: 283-293.

29. Dhawan G, Sumana G, Malhotra BD (2009) Recent developments in urea biosensors. Biochem Eng J 44: 42-52.

30. Ahuja T, Mir IA, Kumar D, Rajesh (2008) Potentiometric urea biosensor based on BSA embedded surface modified polypyrrole film. Sensor Actuat B-chem 134: $140-145$

31. Ahuja T, Kumar D, Singh N, Biradar AM, Rajesh (2011) Potentiometric urea biosensor based on multi-walled carbon nanotubes (MWCNTs)/silica composite material. Mat Sci Eng C 31: 90-94.

32. Kuralay F, Ozyoruk H, Yildiz A (2005) Potentiometric enzyme electrode for urea determination using immobilized urease in poly(vinylferrocenium) film. Sensor Actuat B-Chem 109: 194-199.

33. Lakard B, Herlem G, Lakard S, Antoniou A, Fahys B (2004) Urea potentiometric biosensor based on modified electrodes with urease immobilized on polyethylenimine films. Biosens Bioelectron 19: 1641-1647.

34. Melo, JS, D'Souza SF, Nadkarni GB (1986) Ocimumbasilicum seeds as a pellicular support for immobilizing enzymes. Biotechnol Letters 8: 885-888.

35. Kamath N, Melo JS, D'Souza SF (1988) Grease immobilized on polyethyleneimine cotton cloth. Appl Biochem Biotechnol 19: 251-258.

36. Jha SK, Kanungo M, Nath A, D'Souza SF (2009) Entrapment of live microbial cells in electropolymerized polyaniline and their use as urea biosensor. Biosens Bioelectron 24: 2637-2642.

37. Weatherburn MW (1967) Phenol-hypochlorite reaction for determination of ammonia. Anal Chem 39: 971-974.

38. Silverstein RM, Webster FX (1998) Spectrometric identification of organic compounds (6th edn.) John Wiley \& Sons Inc, New York. pp: 71.

39. D'Souza SF (1999) Immobilized enzymes in bioprocess. Current Sci 77: 69-79. 